\title{
Detection of human papillomavirus DNA sequences in cancer of the urinary bladder by in situ hybridisation and polymerase chain reaction
}

\author{
V Gopalkrishna, A N Srivastava, S Hedau, J K Sharma, B C Das
}

\begin{abstract}
Objective-To evaluate the prevalence of "high risk" human papillomavirus type 16 (HPV 16) in transitional cell carcinoma of the urinary bladder.

Materials and methods-The study included 10 biopsy specimens from male patients of transitional cell carcinoma of the urinary bladder for the detection of HPV DNA sequences. Specimens were collected from the Urology Clinic of the K.G. Medical College Hospital, Lucknow, India. Detection of HPV DNA was carried out by tissue in situ hybridisation (a single copy gene localisation method) using 3H-labelled HPV DNA probe and also by polymerase chain reaction (PCR) techniques using primers to HPV 16 upstream regulatory region (URR).

Results-Out of 10 cases of transitional cell carcinoma of the urinary bladder, "high risk" HPV 16 DNA was detected only in one $(10 \%)$ by using in situ hybridisation whereas two cases $(20 \%)$ were found to be positive by polymerase chain reaction.
\end{abstract}

Conclusion-Our results suggest that the rare occurrence of HPV in bladder carcinoma may not have a causal relation with the viral infection.

(Genitourin Med 1995;71:231-233)

Keywords: HPV; DNA; urinary bladder, carcinoma

\section{Introduction}

Although about 70 human papillomavirus (HPV) genotypes have been associated with benign, premalignant and malignant lesions of the anogenital tract and many other organ sites in humans, the involvement of these viruses particularly of "high risk" HPV types 16 and 18 in urinary bladder carcinoma is not clearly understood. Detection of bovine papillomavirus (BPV) in bladder carcinoma of cattle, ${ }^{12}$ the presence of HPV specific condylomatous lesions $\mathrm{s}^{3-6}$ and HPV antigens in cancer of the bladder in humans ${ }^{7}$ suggest the presence of HPVs in these carcinomas. This has been further strengthened by experimental evidence that injection of cutaneous BPVs into the submucosa of urinary bladder lead to development of fibroma. ${ }^{18}$ Also, HPV DNA has been detected in prostate cancer ${ }^{9}$ and urine samples of men ${ }^{1011}$ and women. ${ }^{12}$ Recently, a low frequency of HPV 16 in tran- sitional cell carcinoma has been detected by in situ hybridisation ${ }^{13}$ and polymerase chain reaction. ${ }^{14}$ But most surprisingly, a very high prevalence of HPV (81\%), particularly the high risk (16 \& 18) types $(62 \%)$ in bladder carcinomas has been reported ${ }^{15}$ recently from Japan. In India, the incidence of HPV, particularly the type 16 in cancer of the uterine cervix is very high $(>90 \%)$ in women. ${ }^{16}$ However, so far no report on HPV prevalence in bladder carcinoma has been available from the Indian population. Since genital condylomata can easily extend to the urethra and urinary bladder, ${ }^{4-617}$ it is not unlikely that HPV infection will be found in these organs. The present study has been carried out to detect HPV DNA in cancer of the urinary bladder in men using both in situ hybridisation and polymerase chain reaction.

\section{Materials and methods}

The study comprised histopathologically confirmed 10 cases of transitional cell carcinoma (TCC) of the urinary bladder in grade II and III subjected to HPV DNA detection by both in situ hybridisation and polymerase chain reaction. Out of 10 cases, 7 were papillary TCC, 2 solid TCC and one was a mixture of both. These cases were registered at the Urology Clinics, K.G. Medical College Hospital, Lucknow. Paraffin embedded tissue sections were used for the in situ hybridisation as well as for the extraction of DNA for the polymerase chain reaction.

\section{Tissue in situ hybridisation}

In situ hybridisation for the detection of HPV DNA in paraffin embedded tissue sections was performed according to the protocols described earlier by us. ${ }^{19}$ Vector-free $8 \mathrm{~kb}$ HPV 16 DNA insert was nick-translated with ${ }^{3} \mathrm{H}$ dCTP, dATP and dTTP (Amersham, England) to a specific activity of $1 \times 10^{8}$ $\mathrm{cpm} / \mu \mathrm{g}$ DNA and was used as probe. Following hybridisation, slides were coated with Kodak NTB2 nuclear track emulsion (Kodak \& Co., USA), incubated for 4 to 6 weeks at $4^{\circ} \mathrm{C}$ and developed in D19B developer. Haematoxylin-eosin stained slides were examined under oil immersion for the presence of silver grains over the cell nuclei as an index of HPV DNA positivity.

DNA extraction and polymerase chain reaction DNA extraction from paraffin sections and polymerase chain reaction (PCR) were carried out according to the methods described earlier \\ Division of Molecular
}


Figure $1 \quad(a, b):$ ISH of tissue sections $(a, b)$ with $3 H$-labelled HPV 16 DNA probe using the single copy gene localization method. tissues analysed only 1 (10\%) contained HPV 16 DNA. Presence of HPV $D N A$ was indicated by deposition of silver grains over the nuclei. The sections were stained with a $H$ and $E$ following hybridisation. urinary bladder carcinoma Of 10 bladder cancer

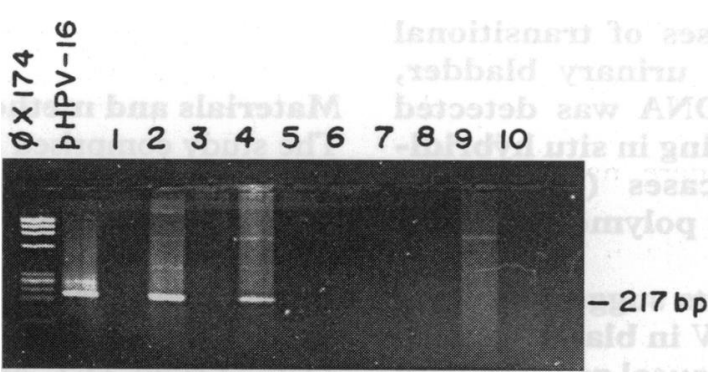

Figure 2 PCR amplification of oligonucleotide primers from the conserved URR region of HPV 16 showing 217 bp amplimer. First lane is Hae III-digested $\emptyset X 174$ DNA size marker Second lane is HPV 16 plasmid DNA, the lanes 1 to 10 are urinary bladder carcinoma DNA samples showing HPV 16 specific amplification of 217 bp in only 2 samples (lanes 2 and 4).

Figure 3 PCR amplification of

oligoprimers from human

$\beta$-globin gene which served as an experimental control. Lanes 1 to 8, all urinary bladder carcinoma DNA, showing 268 bp $\beta$-globin gene amplification. Lane 8 is HPV 16 positive bladder carcinoma sample showing amplification of both $\beta$ globin gene (268bp) as well as HPV 16 DNA (217bp). First three lanes are Hae III-digested $\emptyset X 174$ DNA size markers, HPV 16 plasmid DNA and distilled water showing no globin gene amplification respectively
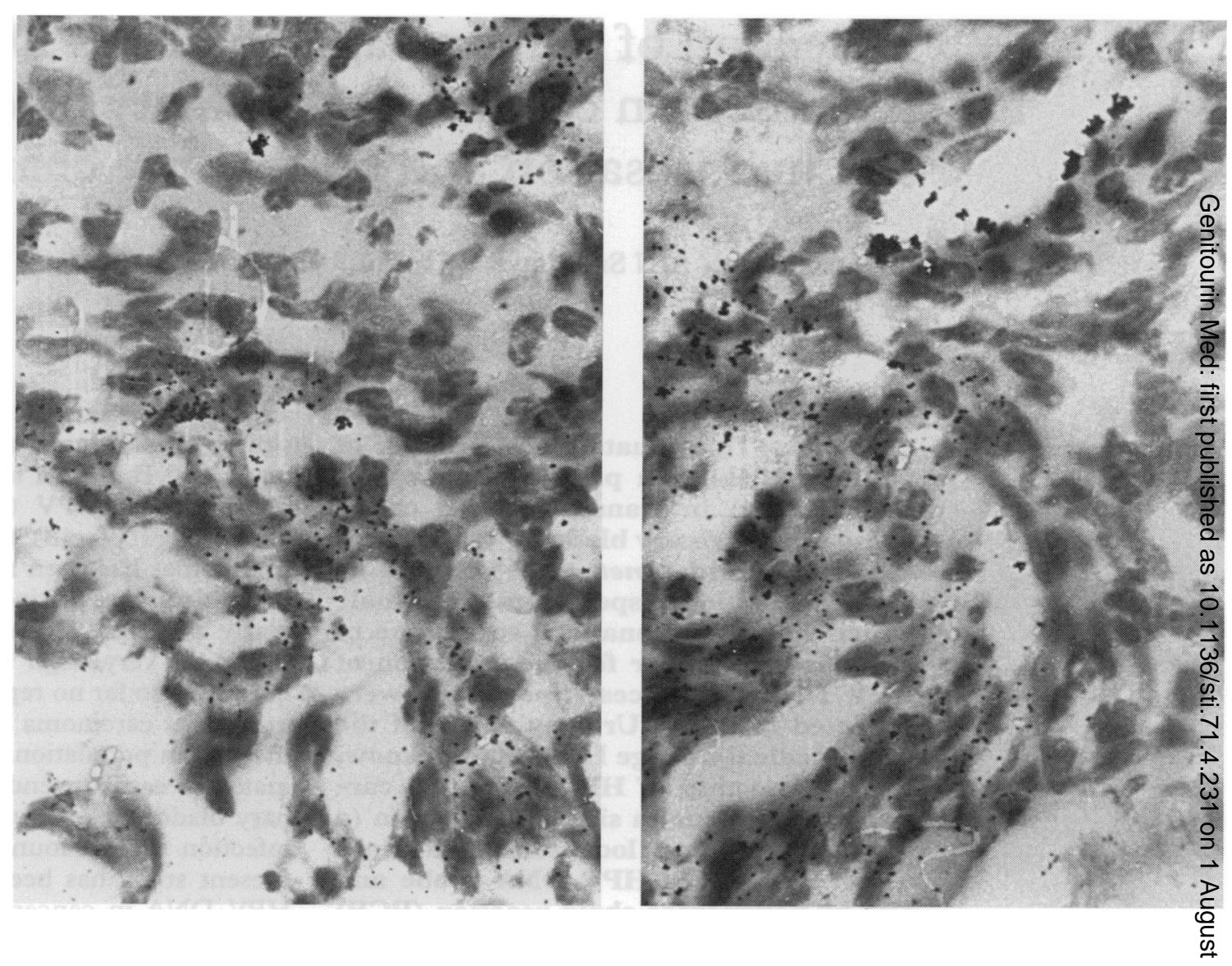

was used as internal experimental controb Twenty microlitres of PCR amplified products were run on 3\% Nusieve agarose gel (FMC BioProducts, Rock Land, USA) alon with Hae III-digested ØX174 DNA marke? Gels were stained in ethidium bromide an photographed by a UV transilluminator.

\section{Results}

Both in situ hybridisation (ISH) and PC techniques have been used to detect the pres: ence of HPV 16 DNA sequences in 10 histo logically confirmed transitional cell carcinom of the urinary bladder. Out of 10 cases of transitional cell carcinoma only one was pose tive by ISH whereas using polymerase chaip reaction, HPV 16 DNA was detected in two cases. Figure $1(\mathrm{a}, \mathrm{b})$ shows the HPV 16 DNA positivity by radioactive ISH in the transis tional cell carcinoma of the urinary bladdef The presence of silver grains can be seen if the majority of cell nuclei (arrows).

Figure 2 shows the HPV 16 DNA positivit in two out of ten bladder carcinoma cases analysed by PCR. An amplified PCR product of $217 \mathrm{bp}$ fragment can be seen in the ethid? ium bromide stained 3\% Nusieve agarose geh Lanes 1-10 are the bladder tumour DN\& samples of which lanes 2 and 4 show HPV $1 \%$ specific $217 \mathrm{bp}$ amplification. The first two lanes on the extreme left represent Hae II digested $\varnothing \mathrm{X} 174$ DNA marker and HPV- $1 \overline{6}$ plasmid DNA amplification respectively? Amplification of $\beta$-globin gene (268bp) which served as an internal control for the experiments is shown in fig 3. Lanes 1 to 8 are bladder carcinoma showing amplification of $\beta$-globin-specific $268 \mathrm{bp}$ fragment. Lane 8 is 
an HPV positive sample showing both $\beta$-globin and HPV specific bands. Of the three lanes on the left, the first is Hae IIIdigested $\varnothing \times 174$ DNA size marker, the other two lanes run with HPV plasmid DNA and distilled water do not show $\beta$-globin amplification respectively. In the present study, HPV 16 DNA frequency by ISH was found to be one in 10 as compared with 2 in 10 by PCR. Since the number of the cases analysed was small, no statistical analysis was employed.

\section{Discussion}

Carcinoma of the urinary bladder is one of the prevalent cancer among males and has been associated with many risk factors for the development of this disease. ${ }^{22-24}$ Although immunological demonstration of papillomavirus common structural antigens ${ }^{72526}$ and observation of HPV-specific cytomorphological features of koilocytotic atypia ${ }^{27-30}$ in urinary bladder carcinomas have provided sufficient ground to believe that HPV may be involved in these tumours, several previous studies have failed to demonstrate HPV DNA in them. ${ }^{31}{ }^{32}$ There have been reports of the presence of condylomatous lesions indicative of HPV 6 and 11 infection ${ }^{2829}$ and also of a case of bladder carcinoma showing HPV 16 positivity with mild immunodeficiency and genital warts. ${ }^{17}$ However, the involvement of "high risk" HPV types 16 and 18 in carcinoma of the urinary bladder has not been established. Recently, there have been two reports showing a low incidence of human papillomavirus type 16 DNA in urinary bladder tumours. ${ }^{1314}$ In the present study, we have also observed a very low prevalence of HPV 16 in transitional cell carcinoma of the urinary bladder by both ISH and PCR. Our observations are in good agreement with the earlier reports. But in sharp contrast to these findings including this report, recently Anwar et al ${ }^{15}$ using PCR assay reported a very high prevalence $(81 \%)$ of HPV in bladder carcinomas as well as in normal urinary bladder specimens (33\%). The frequency of "high risk" HPV types-16, 18 and 33 was also found to be very high $(62 \%)$, a rate much higher than that reported for cervical carcinomas (44\%) in Japan. ${ }^{33}$ It is difficult at present to ascertain such a high prevalence of HPV in urinary bladder carcinoma. This may be because of either technical problems associated with PCR detection of HPV or geographical variations in HPV prevalence. Further study from Japan and other regions would throw light on this aspect.

1 Olson C, Pamukeu AM, Brobst DF. Papilloma like virus from bovine urinary bladder tumors. Cancer Res 1965 from bovine

2 Jarrett WFH. Environmental carcinogens and papillomavirus in pathogenesis of cancer. Proc $R$ Soc London 1987;B231:1-11

3 Lewis HY, Wolf PL, Pierce JM. Condyloma acuminatus of the bladder. F Urol 1962;88:248-51.

4 Murphy WM, Fu YS, Lancaster WD, Jenson AB Papillomavirus structural antigens in condyloma acuminatum of the male urethra. $\mathcal{F}$ Urol 1983;130:84-5.

5 Walther MO, Brien DP, Birch HW. Condylomata acuminata and verucous carcinoma of the bladder. $f$ Uro 1986;135:362-5.
6 Shirai T, Yamamoto K, Adachi T, Imaida K, Masni T, Ito N. Condylomata acuminatum of the bladder in two

7 Bryant P, Skelly J, Wilson D. Demonstration of papillomavirus structural antigen in human urinary bladder neoplasia. Br ₹ Urol 1987;60:405-9.

8 Brobst DF, Olson C. Histopathology of urinary bladder tumors induced by bovine cutaneous papilloma agent. Cancer Res 1965;25:12-9.

9 McNicol PJ, Dodd JG. Detection of human papillomavirus DNA in prostate gland tissue by using the polymerase chain reaction amplification assay. $f$ Clin Microbiol 1990;28:409-12.

10 Melchers EJG, Schift R, Stolz E, Lindeman T, Quint WGV. Human papillomavirus detection in urine samples from male partners by the polymerase chain reaction. 7 Clin Microbiol 1989;27:1711-4.

tion. F Clin Microbiol 1989;27:1711-4.
11 Nakazava A, Inoue M, Fujita M. Detection of human papillomavirus type 16 in sexual partners having cervical cancer by polymerase chain reaction. fapanese fournal of Cancer Research 1991;82:1187-90.

12 Das BC, Gopalkrishna V, Sharma JK, Roy M, Luthra UK. Human papillomavirus DNA in urine of women with preneoplastic and neoplastic cervical lesions. Lancet 1992;340:1417-8.

13 Bryant P, Davies P, Wilson D. Detection of Human Papillomavirus DNA in cancer of the urinary bladder by in situ hybridization. Br f Urol 1991;68:49-52.

14 Chetsanga C, Malmstrom PU, Gyllensten U, MorenoLopez J, Dinter Z, Patterson U. Low incidence of Human Papillomavirus type 16 DNA in bladder tumor detected by the polymerase chain reaction. Cancer 1992; 6etected by the

15 Anwar K, Naiki H, Nakakuki K, Inusuka M. High frequency of human papillomavirus infection in carcinoma of the urinary bladder. Cancer 1992;70:167-73.

16 Das BC, Sharma JK, Gopalkrishna V, et al. A high frequency of human papillomavirus DNA sequences in cervical carcinomas of Indian women as revealed by southern blot hybridization and polymerase chain reaction. F Med Virol 1992(a);36:239-45.

17 Kitamura T, Yoga Y, Veki T, Murakami S, Aso Y. The presence of human papillomavirus type 16 genome in bladder carcinoma in situ of a patient with mild immunodeficiency. Cancer Res 1988;48:7207-11.

18 Lancaster WD, Kurman RJ, Sanz LC, Perry S, Jenson AB Human Papillomavirus: detection of viral DNA sequences and evidence for molecular heterogenecity in sequences and evidence for molecular heterogenecity in
metaplasias and dysplasias of the uterine cervix. metaplasias and dysplasias

19 Das BC, Gopalkrishna V, Das DK, Sharma JK, Singh V, Luthra UK: Human Papillomavirus DNA sequences in adenocarcinoma of the uterine cervix in Indian women. Cancer 1993;72:147-53.

20 Das BC, Sharma JK, Gopalkrishna V, Luthra UK Analysis by polymerase chain reaction of the physical state of human papillomavirus type 16 DNA in cervical preneoplastic and neoplastic lesions. $f$ Gen Virol 1992b;73:2327-36.

21 Sharma JK, Gopalkrishna V, Das BC. A simple method for elimination of unspecific amplifications in polymerase elimination of unspecific amplifications in polym
chain reaction. Nucleic Acids Res 1992;20:6117-8.

22 Morrison AS. Advances in the aetiology of urothelial cancer. Urol Clin North Am 1984;11:557-66.

23 Vaught JB, King CM, Smith PH, Pront GR Jr, eds Bladder Cancer. London: Butterworths 1984:32-45.

24 Hartge P, Hoover R, Kantor A. Bladder cancer risks and pipes, cigars and smokeless tobacco. Cancer 1985;55: 901-6.

25 Roussel F, Pic Quenot JM, Rousseau O. Identification of human papillomavirus antigen in a bladder tumor. Acta Cytologica 1991;35:273-6.

26 Serio G, Pioselli F, Galli L. Immunohistochemical demonstration of papillomavirus structural antigens in urinary stration of papilomavirus structural antigens in urinary
bladder papillary tumors. Pathologica 1990;82:499-505.

27 Del Mistro A, Koss LG, Braunstein J, Halwar M, Koss LG. Identification of human papillomavirus types in male urethral condylomata acuminata by in situ hybridization. Hum Pathol 1987;18:936-40.

28 Querci Della Rovere G, Oliver RTD, McCance DJ, Casho JE. Development of bladder tumor containing HPV type 11 DNA after renal transplantation. $B r f$ Urol 1988;62: 36-8.

29 Mevorach RA, Cos LR, di Sant Agnose PA. Human papillomavirus type 6 in grade 1 transitional cell carcinoma of the urethra. F Urol 1990;143:126-8.

30 Wilson RW, Chengiss ML, Unger ER. Longitudinal study of human papillomavirus infection of the female urogenof human papillomavirus infection of the female urogen-
ital tract by in-situ hybridization. Arch Pathol Lab Med

31 Green M, Orth G, Wold WSM, Sanders PR, Mackey JK, Favre M, Croissant $O$. Analysis of human cancers, normal tissues and verruce plantares for DNA sequences of human papillomavirus types 1 and 2. Virology 1981 110:No:176-184

32 Kahn T, Schwarz E, zur Hausen H. Molecular cloning and characterization of the DNA of a new human papilloma virus (HPV 30) from a laryngeal carcinoma. Int $\mathcal{f}$ Cancer 1986;37:61-5.

33 Yoshikawa H, Matsukura T, Yamamola E, Kawana T, Mizuno M, Yoshike K. Occurrence of human papillomavirus type 16 and 18 DNA in cervical carcinomas from Japan: Age of patients and histological type of carcinomas. Fapan fournal of Cancer Research (Gann) 1985;76:667-71. 